\title{
Climate Change and Rice Production: A Case Study in Ekiti State, Nigeria
}

\author{
R. M. Olanrewajuํㅗ․ S. L. Tilakasiri and C. Oso \\ Received: 03 ${ }^{\text {rd }}$ August 2016 / Accepted: $10^{\text {th }}$ January 2017
}

\begin{abstract}
The paper explores the climate effect of rice produce in Ekiti State Nigeria. Climate data was obtained from the archive of the Nigerian Meteorological Station, Oshodi, Nigeria. The Rice data was obtained from Ekiti State Agricultural Development Project (A.D.P) The climatic parameters are rainfall amount, rainfall frequency, maximum and minimum temperature while rice yield data include land devoted to rice cultivation, rice production and yield. The data covered the period of 5yrs between 2007 and 2011. The climate data were grouped based on the rice cropping calendar of the study area into the pre-planting (Feb), the planting season (March-mid April), the period of growth (mid April- July) and the period of harvest. The data were summarized using statistical tool of mean, Correlation and regression were used to find the strength of relationship while the most critical climatic variable(s) for rice was identified using factor analysis. The result showed that increase in land devoted to rice did not bring corresponding increase in rice yield. Increase in rainfall amount and frequency during the period shortly before planting and during planting seems to be very important for rice yield. Minimum temperature correlates highly with yield during the period of planting. Mild positive relationship exists between yield and temperatures (maximum and minimum). Temperature is most critical during harvest as both maximum and minimum temperature exhibited a high positive relationship of 0.82 and 0.66 respectively.
\end{abstract}

Keyword: Climate Change, Upland Rice, Rainfall, Temperature, Yield.

\section{INTRODUCTION}

Agriculture in Nigeria like any other tropical developing country is rain-fed and hence climate determined. Variations in climatic factors mostly rainfall and temperature correlate with crop production and yield in Nigeria (Adebayo, 1998; Tybee, 2006; Bello, 2010; Olanrewaju, 2009; Sawa and Adebayo, 2011; Mohammad et. al., 2011; Asikhia and Igbafen, 2012). The result of the above studies shows that climate variability is a threat to food security. Occurrence of abnormal weather episodes results in crop yield reduction, thus to make Nigeria self sufficient in rice production, the issue of climatic vagaries needs be tackled.

Recent studies both in Nigeria and outside attributed low production of rice to impacts of climate change. Such include, Auffhammer
(2011), Ayinde et al. (2013), Besir and Ceylan (2013), Ugwu (2013) and Scharticles (2014) among others. Auffhammer, (2011) used a combination of statistical and simulation methods to analyse impact of the changing monsoon rainfall pattern on rice production in Asia. The result shows that drought and extreme rainfall consequent of climate change negatively affect rice yield in predominantly rain fed areas during the period of 1966 - 2002 with drought having a much greater impacts than extreme rainfall. Similarly, an assessment of the effect of climate change on rice production in Anambra State Nigeria was carried out by Nwalieji and Usuegbunam (2012) using purposive and random sampling techniques to seek the opinions of people on the subject. The major perceived causes of climate change as identified 
were deforestation, bush burning and extreme use of agro-chemical in rice production. The result further shows a serious negative effect of climate change on rice production which manifested in reduction of crop yield and grain quality, destruction of farm land (including rice farm land) by flood, high incidence of weeds, pests and diseases.

In the same vein, Ayinde et al. (2013) evaluated the effects of climate change on rice production in Niger State, Nigeria using analytical tools of descriptive analysis, unit root and co-integration. The result reveals humidity and minimum temperature as the most critical climatic factors for rice cultivation in the area. For instance an increase in humidity of $1 \%$ brings about $17 \%$ reduction in rice production. However, such increase in minimum temperature results in $52.3 \%$ increase in rice production. Bersir and Ceylan (2013) in their own study observed global warming as a threat to rice production in Turkey. Scharticles (2014) identified environmental factors such as irregularity in rainfall pattern, increase in temperatures attributable to climate change as problems facing rice production in Nigeria.

Ugwu (2013) listed weather vagaries among other factors challenges of rice production in Nigeria. FAO (1996) corroborate this further by identifying erratic and poor rains in rain fed agricultural upland ecosystem of Africa as constraint because they make rice production highly vulnerable to drought. These factors are responsible for low rice production in Nigeria. Thus to make Nigeria self-sufficient in rice production there may be need to examine the influence of climate on rice production which this research work focuses on for Ekiti State, Nigeria.

Although rice is grown in almost all the agroecological zones in Nigeria, its production has not entered the international market and the supply has not met the demand in most of the producing area. Ekiti state is one of such areas
(NISER, 2002), thus the need for this research efforts.

Rice has been described as a staple food of every household in Nigeria. Both the rich and poor consume large quantity of rice every day. Uba (2013) noted that $70 \%$ of a total projected population of Nigeria feed on rice. As at the end of year 2012 the total foreign debt and importation figures of rice amount to about one trillion of naira, thus making importation of rice to have the greatest figure of over $60 \%$ of total import figures. According to Uba (2013), the federal government of Nigeria is advised to take some corrective measures to overcome this situation. The purpose of this research is to examine the impacts of climate change on the production of upland rice in Ekiti State of Nigeria with the aim of proffering lasting solution to the inadequate production of rice in the area.

\section{MATERIALS AND METHODS}

\section{The study area}

Ekiti State the study area is located between longitude $4^{\circ} 5^{\prime}$ and $5^{\circ} 45^{\prime}$ East of the Greenwich Meridian and between latitude $7^{\circ} 15^{\prime}$ and $8^{\circ} 5^{\prime}$ North of the equator (Figure 01). Ekiti State enjoys the tropical climate with two distinct seasons. This climate is controlled by two surface opposing winds namely the NorthEast trade wind which blows during the dry season and the South-westerly wind which prevails during the rainy season. Rainy season spans between April and October and the dry season between November and April with air temperature ranges between $21^{\circ} \mathrm{C}$ and $28^{\circ} \mathrm{C}$.

The study area is underlain by metamorphic rock of the basement complex. It is an upland area of over 250 meters above sea level. Ekiti has tropical rain forest vegetation in the South and savannah vegetation in the Northern fringes. 


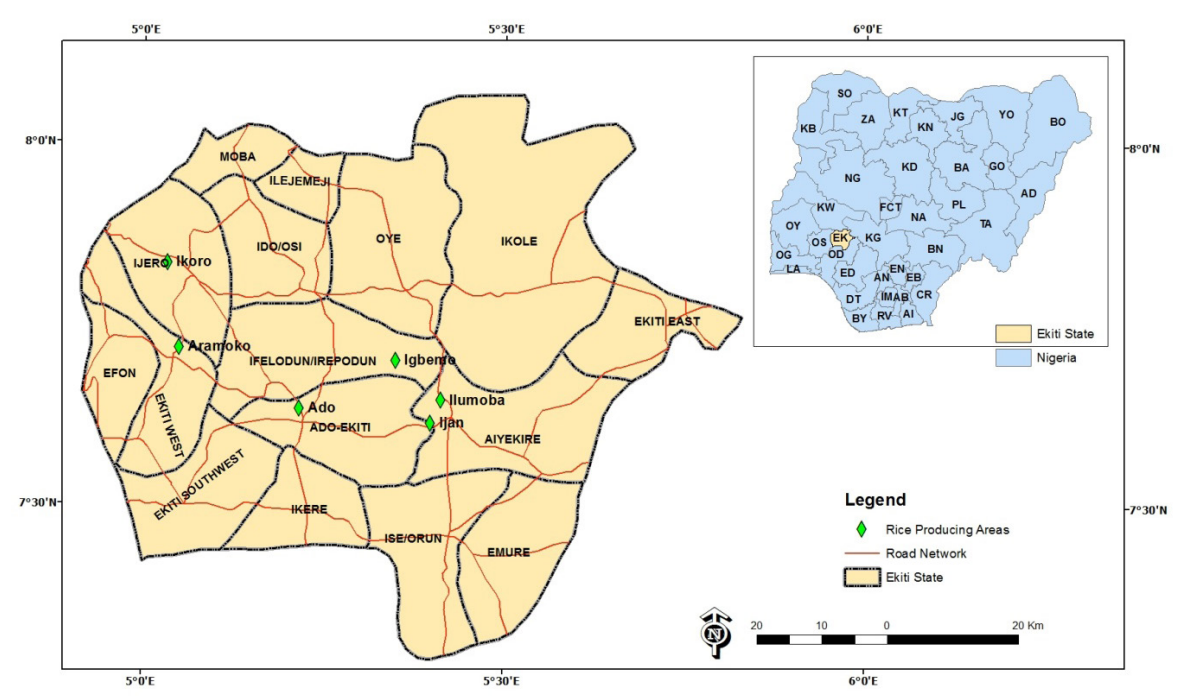

Figure 01: Map of Ekiti State Showing the Rice Producing Areas

Farming constitutes the major socio-economic activities of the people. Farmers cultivate both roots and grain crops and the community is noted for rice production. Ugwu (2014), described Ekiti as one of the leading 13 rice producing states in Nigeria. The major settlements where rice is the major crop produced are Igbemo, Ilumoba, Ijan, Ado, Aramako and Ijero.

\section{Sources of data}

The climatic data was sourced from archive of the Nigerian Meteorological Station, Oshodi, Lagos while the rice data was obtained from the Ekiti State Agricultural Development Project. The data covered 5 years period that spanned between 2007 and 2011. The climatic data used were rainfall amount, rainfall frequency, maximum and minimum temperature. According to Ayoade (2004) rainfall and temperature represent the most critical climatic parameters for crop production in Nigeria. The rice data collected include area devoted to upland rice cultivation, production and yield. Climatic data were collected on daily basis but partitioned based on the rice cropping calendar of the study area into the pre-planting period, (February), the planting season (Mid April-July) and the period of harvesting (July-August). This helped in examining the weather that prevail shortly before rice planting (February), during planting (mid March-mid April), during its growth in the field (mid April-July) and during the period of harvesting (July-August) rice crop.

Descriptive statistic of mean was calculated to produce a quantitative summary of the data which was tabulated. Inferential statistics of correlation and multiple regressions were also employed in this study. Correlation Coefficient is a statistical measurement which describes the degree of association between two or more variables (Nwosu, 1998). It describes relationship. It can be negative, positive, high, low or zero. In this study the degree of association (the strength in relationship) between climatic variables and rice yield in Ekiti State of Nigeria was calculated. Linear regression measures both association and prediction between two data set. It is estimated with the formular $\mathrm{Y}=$ $a+b x$

where

$\mathrm{Y}=$ dependent variable

$\mathrm{x}=$ independent variable

$a=$ intercept on $y$-axis

$b=$ slope coefficient

Climatic variables represent the independent variable while rice yield is the dependent variable in this study. 
Factor analysis was also used to bring out the climatic variable(s) that is most critical for rice production in the area.

\section{RESULT AND DISCUSSION}

\section{Land devoted to upland rice cultivation and production}

The relationship between land put into rice cultivation and production is shown in Figure 02 . To increase production more land has to be devoted to rice cultivation. Basorun and Julius (2012) identified area devoted to rice cultivation as one of the crucial factors impacting rice cultivation in the area.

During the year 2007, to reach production level of 68.9 ('000MT') 49.51 ('000Ha') of land was cultivated. The gap between production and land devoted to cultivation of rice widened progressively throughout the period of study. This kind of farmland expansion could lead to mismatch of environment and rice cropping which will eventually result in rice cropping - climate mal - adjustment. Yield of rice between 2007 and 2011 is reflected in Figure 03.

Although there is an increase in rice yield between 2007 and 2010 however this increase does not commensurate with the increase in the land devoted to rice cultivation on annual basis. In year 2011 a decline in rice yield occurred in spite the increase observed in land cultivated and in production. Factors responsible for such discrepancy need be investigated and address promptly for efficient production of rice in the area. Thus the climatic pattern during the rice cropping season is investigated into in the next section.

\section{Pattern of climatic variables during the upland rice cropping season}

The Climate of the Pre-planting Season (February) 2007 and 2011.

Table 01 reflects the climatic pattern in February which represents the period shortly before an upland rice planting in Ekiti State, Nigeria between year 2007 and 2011.

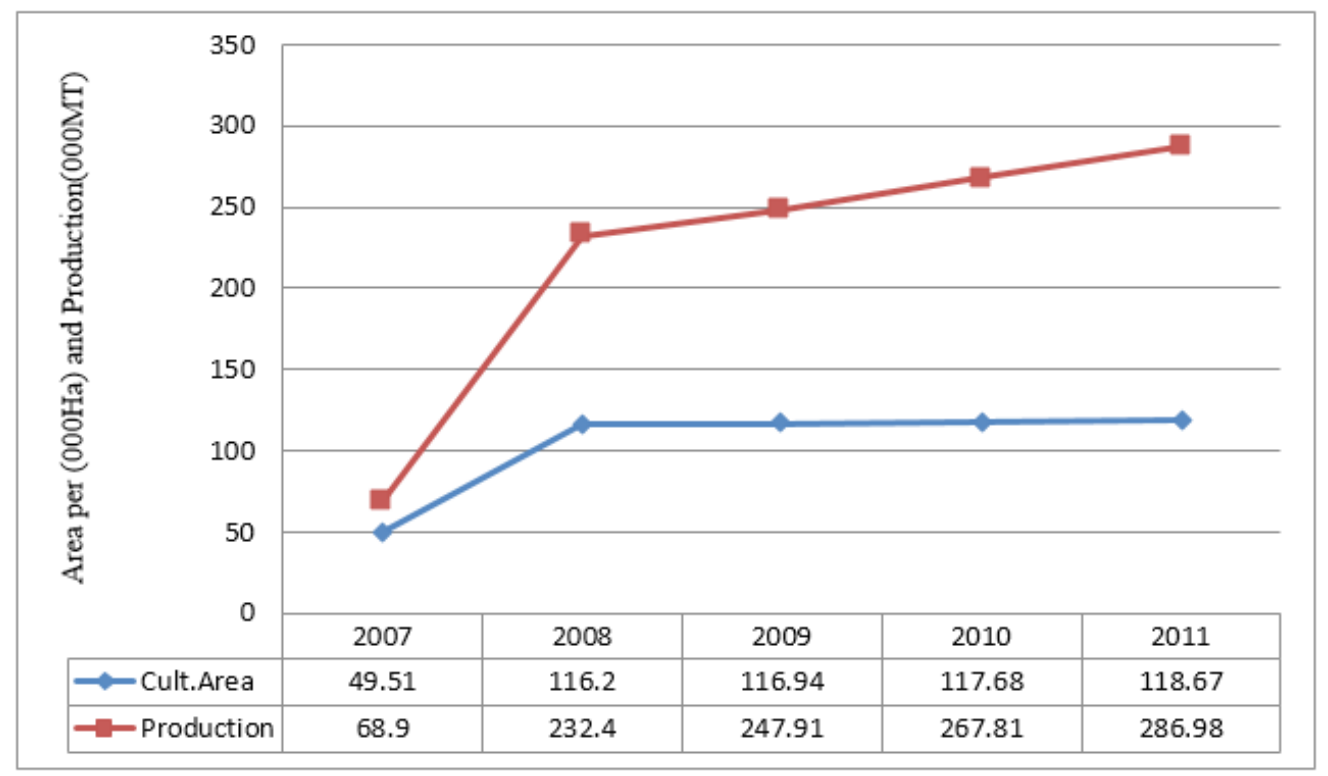

Source: Authors' Fieldwork (2014).

Figure 02: Comparison between Lands Devoted to Upland Rice Cultivation and Production. 


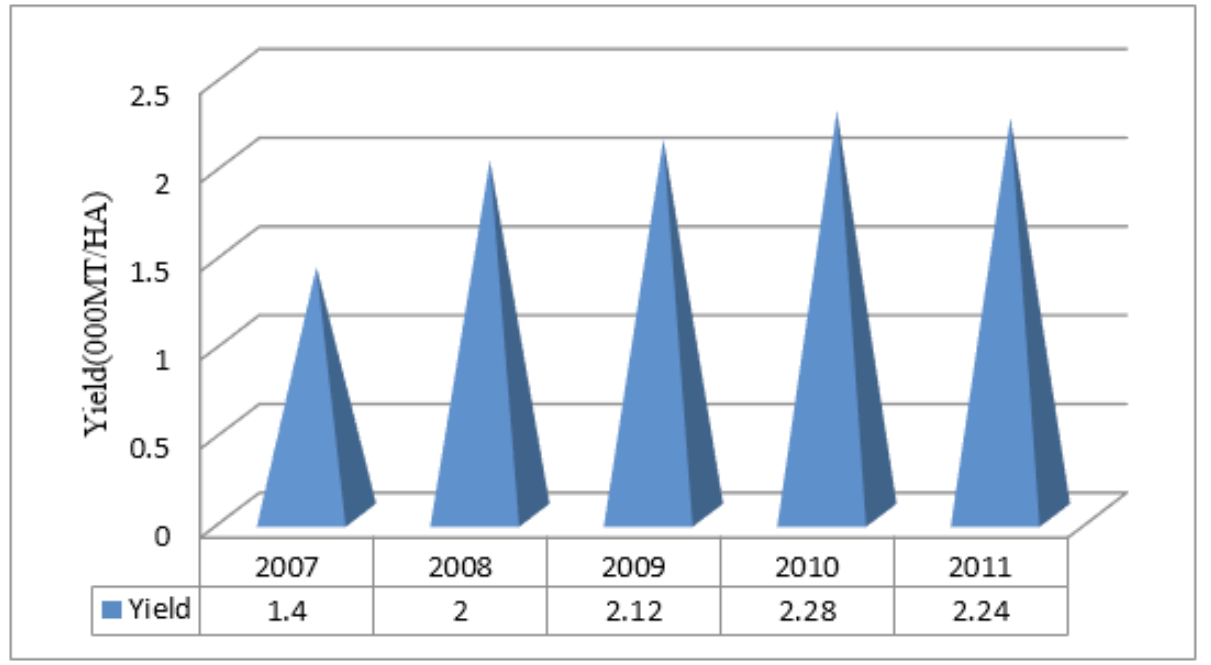

Source: Authors' Fieldwork (2014).

Figure 03: Rice Yield (000MT/HA) in Ekiti State (2007-2011)

Rainfall amount in February fluctuated during the period of study. For instance only year 2008 did not record any rainfall out of the five years considered. Highest rainfall of $88.1 \mathrm{~mm}$ was observed in year 2011 this made this year the wettest of all during this period. This is followed by year 2007, 2009 and 2010 while year 2008 was the driest (Figure 04).

The distribution of rainfall frequency during this period did not follow that of rainfall amount. For instance, years 2007, 2009 and 2010 that received $52.6 \mathrm{~mm}, 48.9 \mathrm{~mm}$ and $25.6 \mathrm{~mm}$ of rainfall observed similar rainfall frequency of 4 each. Only year 2011 has a corresponding increase in rainfall frequency with rainfall amount. The implication is that, February rainfall was most torrential in year 2011 .

February maximum temperature was high and ranged between $36^{\circ} \mathrm{C}$ in 2007 and $34.1^{\circ} \mathrm{C}$ during year 2009 and minimum temperature varied between $17.2^{\circ} \mathrm{C}$ in year 2011 and $21.1^{\circ}$ $\mathrm{C}$ in year 2007 (Figure 05).

\section{The climate of the planting season of upland rice (Mid March-Mid April) 2007-2011}

Table 02 shows the climatic pattern during the planting season of rice between 2007 and 2011. Rainfall amount and frequency of the period between mid March and mid April fluctuated. There is an increase in rainfall amount and frequency as compared with the February situation. Year 2007 was the driest month $(72.2 \mathrm{~mm})$ while 2011 still maintain the highest rainfall amount of $158.1 \mathrm{~mm}$ that was well spread. The dryness of the pre planting season during 2008 was compensated for during the planting season of upland rice (Figure 06).

Table 01: Climatic pattern shortly before upland rice planting (February)

\begin{tabular}{lcccc}
\hline Year & $\begin{array}{c}\text { Rainfall Amount } \\
(\mathrm{mm})\end{array}$ & Rainfall Frequency & $\begin{array}{c}\text { Maximum } \\
\text { Temperature }{ }^{0} \mathrm{C}\end{array}$ & $\begin{array}{c}\text { Minimum } \\
\text { Temperature }{ }^{0} \mathrm{C}\end{array}$ \\
\hline 2007 & 52.6 & 4 & 36 & 21.1 \\
2008 & 0 & 0 & 34.6 & 19.6 \\
2009 & 48.9 & 4 & 34.1 & 19.4 \\
2010 & 25.6 & 4 & 35.9 & 19.8 \\
2011 & 88.1 & 5 & 34.2 & 17.2 \\
\hline
\end{tabular}

Source: Authors' Computation (2014). 


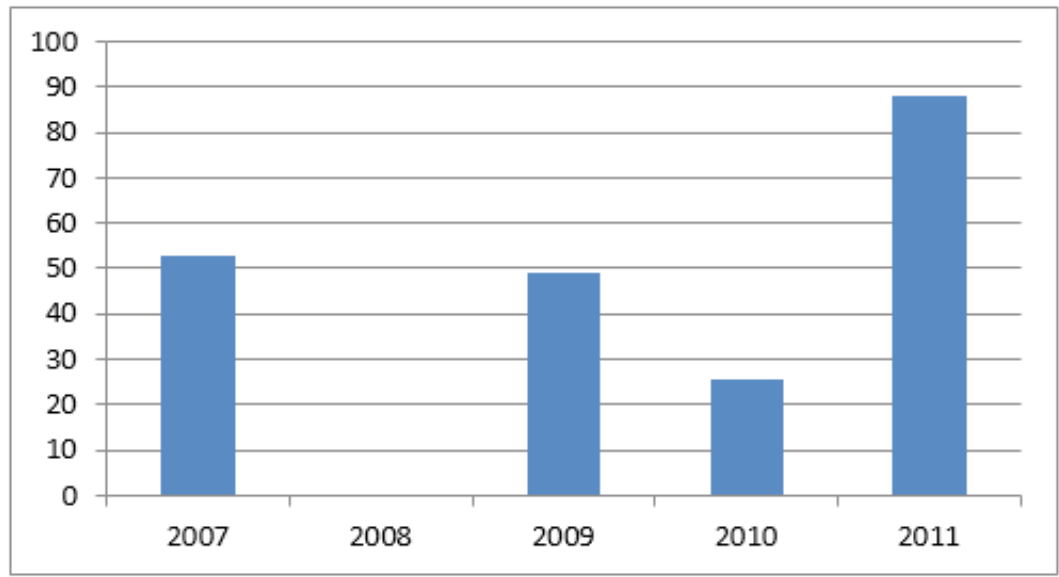

Source: Authors' Fieldwork (2014)

Figure 04: Rainfall (mm) Pattern shortly Before an Upland Rice Production.

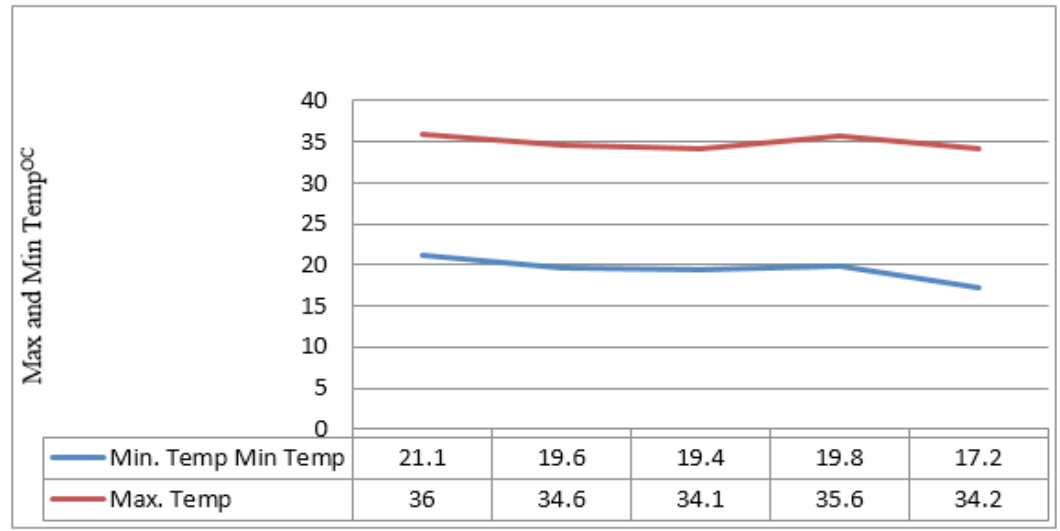

Source: Authors' Fieldwork (2014)

Figure 05: Maximum Temperature $\left({ }^{\circ} \mathrm{C}\right)$ and MinimumTemperature $\left({ }^{\circ} \mathrm{C}\right)$

Table 02: Climatic pattern during the planting season of upland rice

\begin{tabular}{lcccc}
\hline Year & $\begin{array}{c}\text { Rainfall Amount } \\
(\mathrm{mm})\end{array}$ & Rainfall Frequency & $\begin{array}{c}\text { Maximum } \\
\text { Temperature }\left({ }^{\circ} \mathrm{C}\right)\end{array}$ & $\begin{array}{c}\text { Minimum } \\
\text { Temperature }\left({ }^{\circ} \mathrm{C}\right)\end{array}$ \\
\hline 2007 & 72.2 & 7 & 34.9 & 21.2 \\
2008 & 129.5 & 8 & 33.3 & 22.6 \\
2009 & 157.9 & 8 & 33.0 & 23.6 \\
2010 & 74.3 & 7 & 33.2 & 23.4 \\
2011 & 158.1 & 11 & 33.0 & 22.6 \\
\hline
\end{tabular}

Source: Authors' Computation (2014).

Air temperature was high throughout the period Year 2007 that received the least rainfall amount under consideration but not as high as the during this period was also the hottest of all with period shortly before rice planting i.e. February air temperature reaching about $35^{\circ} \mathrm{C}$.

(Figure 07). 


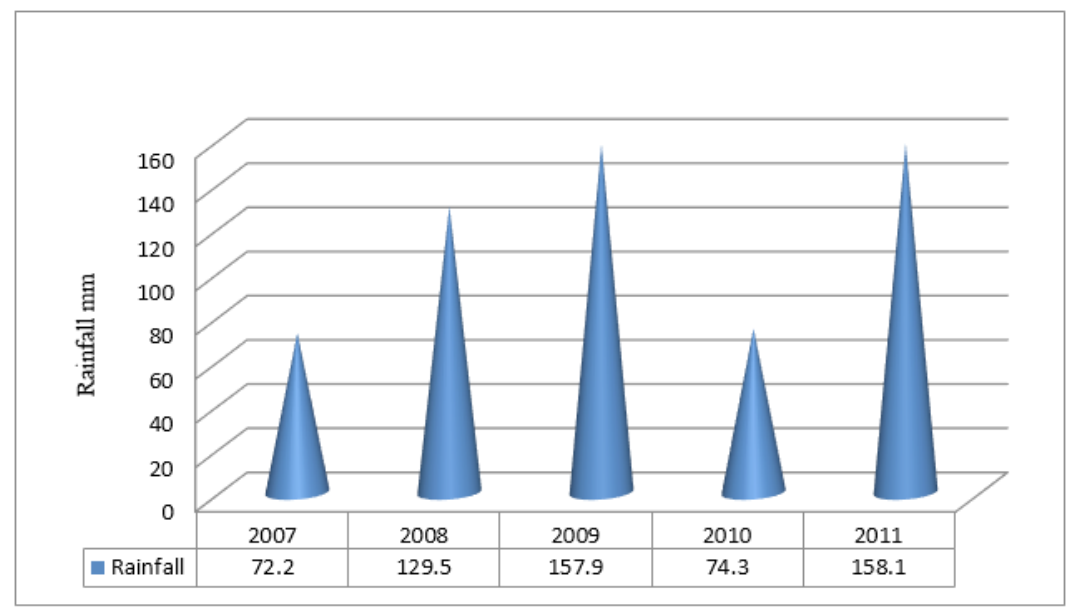

Source: Authors' Fieldwork (2014)

Figure 06: Rainfall Amount (mm) during Upland Rice Planting Season (mid March-mid April)

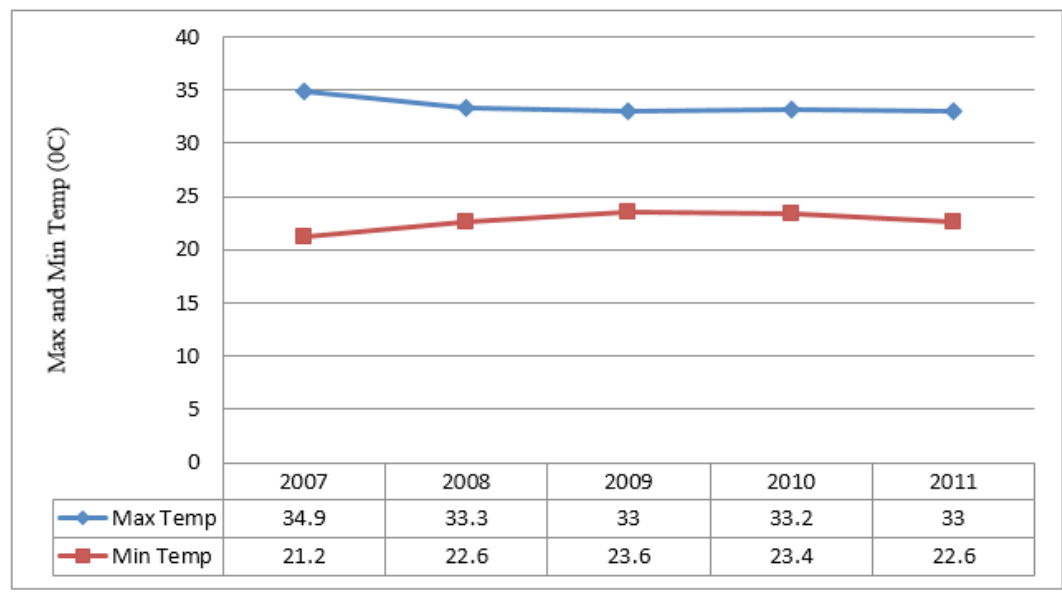

Source: Authors' Fieldwork (2014)

Figure 07: Temperature ${ }^{0} \mathrm{C}$ during Upland Rice Planting Season (mid March-mid April)

The Climate of the Growing Season of Upland Rice (Mid April-July)

Upland rice planted between mid March and mid April reaches maturity stage in July. The climatic pattern during this period is shown in Table 03.

The season represents the first peak of rainfall in the study area. During this season, the study area is under the influence of the moisture laden Southwest monsoon wind. Rainfall amount and frequency is highest during this season. Year 2009 recorded the highest rainfall amount of $693.3 \mathrm{~m}$ and the least amount of 438.6 was recorded in year 2010 (Figure 08). Temperature is uniformly high during this season.

The highest maximum temperature of $30.81{ }^{\circ} \mathrm{C}$ was recorded in 2008 and 2011. Maximum temperature ranged between $30.3^{\circ} \mathrm{C}$ and $30.81^{\circ} \mathrm{C}$ while minimum temperature ranged between $21.3^{\circ} \mathrm{C}$ and $23.6^{\circ} \mathrm{C}$ respectively (Figure 09). When compared with the previous pattern a decline in air temperature occurred. This reduction in air temperature is accounted for by the overcast of cumulous cloud during this season which shields the surface from the direct effect of the scorching sun. 
Table 03: Climatic pattern of the growing season of rice crop

$\begin{array}{ccccc}\text { Year } & \text { Rainfall Amount } & \text { Rainfall Frequency } & \text { Maximum Temperature } & \text { Minimum Temperature } \\ 2007 & 611.6 & 52 & 30.5 & 22.6 \\ 2008 & 626.1 & 45 & 30.81 & 21.3 \\ 2009 & 693.3 & 45 & 30.3 & 23 \\ 2010 & 438.6 & 45 & 30.5 & 23.4 \\ 2011 & 530.9 & 37 & 30.81 & 23.6\end{array}$

Source: Authors' Computation (2014)

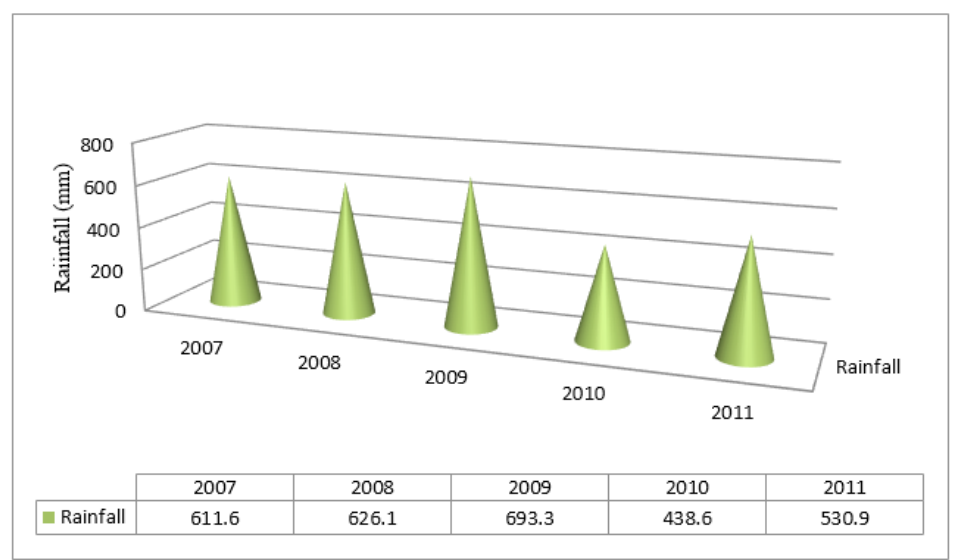

Source: Authors' Fieldwork (2014)

Figure 08: Rainfall Pattern during the Growing Season of Upland Rice

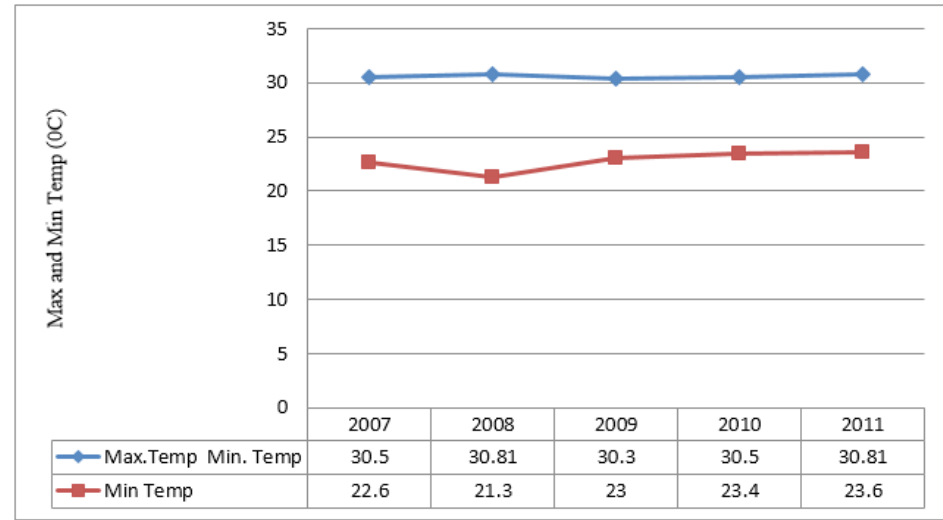

Source: Authors' Fieldwork (2014)

Figure 09: Temperature Pattern during the Growing Season of Upland Rice (mid April-July)

Climatic pattern at the period of rice harvesting that characterized the previous seasons of rice in Ekiti State (July-August).

Table 04 reflects the pattern of climate displayed during July-August harvesting season of upland rice in Ekiti State, Nigeria between year 2007 and 2011. growing is mildly displayed here. However the highest rainfall amount was observed during year 2008 and year 2010 that recorded the highest rain fall between mid March/ mid April and July observed the least rainfall amount under the climatic condition of July-August Fluctuation in rainfall amount and frequency (Figure 10). 
Highest rainfall value of $450.2 \mathrm{~mm}$ was received in year 2008 and the least value of $290.4 \mathrm{~mm}$ occurred in year 2009. Generally, there was a decline in rainfall amount and frequency as compared with the previous rice season. The drop in rainfall values observed is linked with the occurrence of the little dry spell of August break that characterized the weather pattern of this season.

Temperature dropped further and this period represents the coolest weather of all the stages of upland rice cropping considered. Maximum temperature ranged between $27.3^{\circ} \mathrm{C}$ (observed in 2007 ) and $28.4^{\circ} \mathrm{C}$ in 2011 while minimum temperature was between $21.2^{\circ} \mathrm{C}$ (of 2007 and 2008) and $22^{\circ} \mathrm{C}$ recorded during year 2009 (Figure 11). Air temperature dropped during this rice cropping season in response to the temperature inversion which is the major cause of the dry spell of August break.

Table 04: Climate pattern during July-August harvesting season between 2007 and 2011

\begin{tabular}{rcccc}
\hline Year & Rainfall Amount & Rainfall Frequency & Maximum Temperature & Minimum Temperature \\
\hline 2007 & 426.9 & 40 & 27.3 & 21.2 \\
2008 & 450.2 & 30 & 28.2 & 21.2 \\
2009 & 290.4 & 23 & 27.6 & 22.0 \\
2010 & 448 & 33 & 28.1 & 21.7 \\
2011 & 348.7 & 23 & 28.4 & 21.7 \\
\hline
\end{tabular}

Source: Author's Computation (2014)

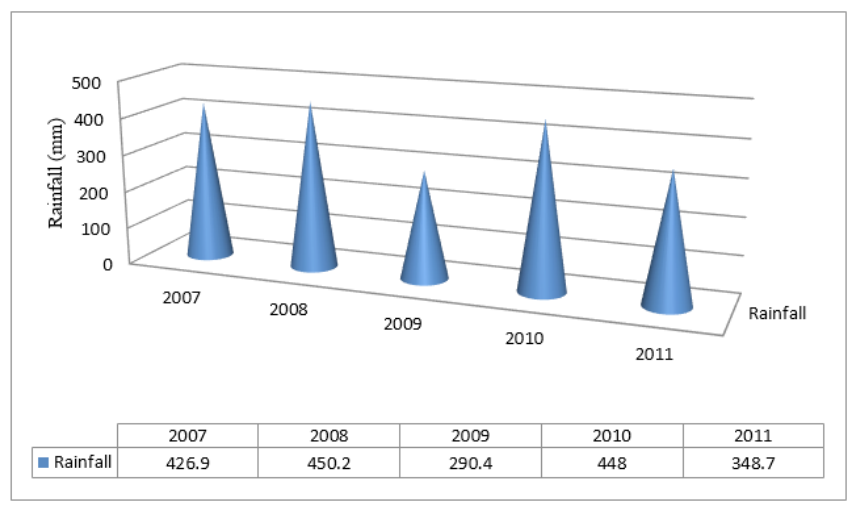

Source: Authors' Fieldwork (2014)

Figure 10: Rainfall Pattern during the Harvesting Season of Upland Rice (July-August)

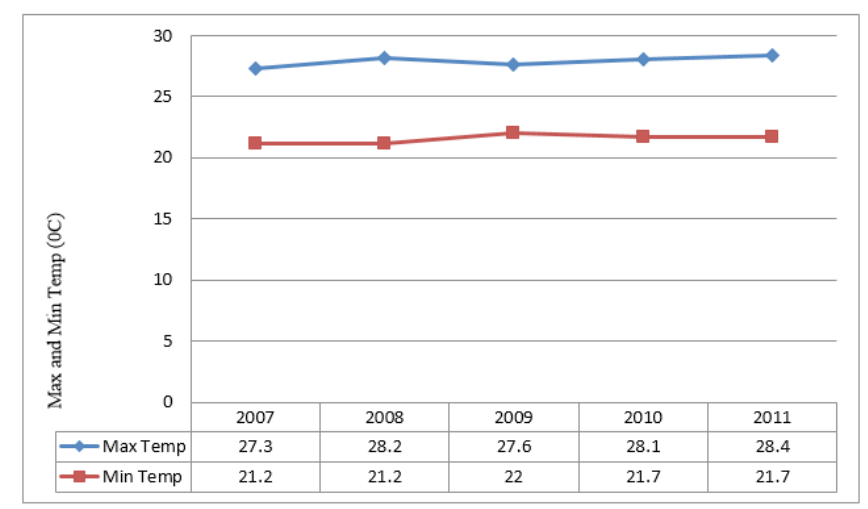

Source: Authors' Fieldwork (2014)

Figure 11: Temperature Pattern during the Harvesting Season of Upland Rice (July-August). 


\section{Effect of climate on yield of upland rice}

\section{Effect of the weather pattern of February on upland rice yield in Ekiti State}

When the yield of upland rice was compared with the climatic pattern of the pre-planting season, it appears high rainfall amount that is well distributed coupled with low maximum and minimum temperature during this period enhanced the yield of upland rice. For instance, year 2011 that satisfied these requirements observed the highest yield. Again, year 2007 that observed low rainfall amount and frequency, highest maximum temperature of $36^{\circ} \mathrm{C}$ and minimum temperature of $21.1^{\circ} \mathrm{C}$ recorded the least yield.

\section{Effect of weather pattern of mid March and mid April (planting season) on upland rice yield in Ekiti State}

Similarly, yield of rice is likely to be boosted by high rainfall amount, high rainfall frequency, lower maximum temperature but higher minimum temperature during the planting season of rice in mid March-Mid to April. This is because year 2011 that recorded the highest yield observed the highest rainfall amount of $158.1 \mathrm{~mm}$ and rainfall frequency of 11 . Contrary wise, year 2007 that observed the lowest rainfall amount of $72.2 \mathrm{~mm}$ spread over 7 rain days. The exception of this year 2010 when little increase in rice yield occurred with a decline in rainfall amount and frequency. This increase is probably resulted from the expansion of land under rice cultivation.

\section{Effect of weather pattern between mid March and July on upland rice yield in Ekiti State}

The above period cover the time of rice planting through maturity in the field. This represents the period of the first peak of rainfall in the area. Although rainfall amount and frequency were generally high, the period of the highest rainfall and rainfall frequency did not coincide with the period of highest yield. Yield increased with increase in rainfall amount between 2007 and 2009. A decline in rainfall amount but with a consistent rainfall frequency brings about increase yield. In 2011 a decline in rainfall frequency was compensated for by an increase in rainfall amount and this brought about increase in rice yield. It appears minimum temperature influence yield than maximum temperature during this period. Increase in minimum temperature resulted in increase in yield with the exception of year 2008. Although rice require lot of water while growing in the field however, being an upland varieties it has its own limited water requirement to performed optimally in the field

\section{Effect of weather pattern of July-August on yield of rice}

This represents the period of rice harvest it appears high rainfall amount and frequency do not support rice yield during this stage if rice plant. Rainfall amount and frequency were lowest in year 2011 that reported the highest yield $(238.7 \mathrm{~mm}$ and $23 \mathrm{~mm})$ compared with $426.9 \mathrm{~mm}$ and frequency of 40 reported in the year 2007 that observed the lowest yield. Generally, yield increased steadily with decline in rainfall frequency during this period with the exception of year 2010 for same reason given.

The result of ANOVA on the relationship between the areas devoted to rice cultivation and rice production showed that the regression is positive and significant (Table 05). Area of rice cultivation exhibited a very high positive correlation of 0.93 and the model summary in table below showed that expansion of land devoted to rice cultivation yearly between 2007 and 2011 gave $86 \%$ explanation for the increase in yield experienced during the period of study. 
The implications of this yearly expansion in area devoted to rice cultivation have beclouded the effects of every other environmental stressors including climate. This is risky because the delicate equilibrium between climate and rice production can be upset, thus bringing about mal-adjustment agriculture that will result in poor future yield of rice in the study area. This is because there is the tendency for rice farmers in the study area to go beyond environmental potential tolerance limits for rice cultivation.

For an increase in area cultivated where ' $a$ ' is constant $=1$. The yield of rice is expected to increase by 0.798

$\mathrm{Y}=0.798+0.926 \quad$ (Area of rice cultivated) $\mathrm{Y}=\mathrm{a}+\mathrm{bx}$.

The results of the Pearson Correlation between rice yield and climatic variables at different stages of rice cultivation is reflected in Table 06.

Rainfall frequency and amount showed a weak positive correlation during the pre-planting period of rice cultivation. However, maximum temperature and minimum temperature displayed a strong negative relationship with rice yield during this period. The implication is that moderate rainfall is required during the planting season of rice while high temperature most especially high minimum temperature is a nuisance to upland rice crop cultivation at this season.

Planting season of rice (mid March/April) required more rainfall and less heat. Thus, a strong positive relationship of 0.6 and 0.55 exist between rainfall amount, rainfall frequency and yields during this season. Also minimum temperature exhibited a strong positive relationship of 0.79 i.e. the higher the minimum temperature the higher the yield of rice. Maximum temperature however does not support rice yield as it displayed a very strong negative relationship of -0.94 during this rice growth stage.

The period of rice growth in the field(Mid MarchJuly) displayed a mild negative relationship with rainfall, mild positive relationship with both maximum and minimum temperature. This may be attributed to the fact that the variety is an upland rice type which may not require as much moisture as swamp rice. Again the influence climate has on upland rice in the area has been beclouded by the rapidity at which area devoted to upland rice cultivation expand.

Table 05: Model summary of the correlation between areas devoted to rice cultivation and yield (2007-2011).

\begin{tabular}{ll}
\hline Variable & Yield \\
\hline Area cultivated & 0.93 \\
\hline
\end{tabular}

Source: Authors' Computation (2014).

Table 06: Result of Pearson correlation between rice yield and climatic variables at different stages of rice cultivation.

\begin{tabular}{lcccc}
\hline \multicolumn{1}{c}{ Variables } & February & Mid March-April & Mid March-July & July-August \\
\hline Rainfall & 0.20 & 0.60 & -0.90 & -0.78 \\
Frequency & & & & \\
Rainfall Amount $(\mathrm{mm})$ & 0.20 & 0.55 & -0.42 & -0.32 \\
Maximum Temperature ${ }^{0} \mathrm{C}$ & -0.54 & -0.94 & 0.32 & 0.82 \\
Minimum Temperature ${ }^{\circ} \mathrm{C}$ & -0.83 & 0.79 & 0.20 & 0.66 \\
\hline
\end{tabular}

Source: Authors' Computation (2014). 
The mild positive relationship rice yield exhibited with maximum temperature agreed with the findings of Olanrewaju (2010) for the Niger River Basin Development Authority Area.

The strong negative relationship exists between rainfall frequency and rice yield but mild with rainfall amount during the period of harvesting. Contrary wise, both maximum and minimum temperature showed a strong positive relationship. The implication of these results is that high rainfall frequency and amount are nuisance during harvesting season and are not required but high temperature constitutes an assert as it helps in the drying up of rice seeds.

Generally, the regression line equation for yield versus climatic variables is

$\mathrm{Y}=\mathrm{a}+\mathrm{bx} 1=\mathrm{bx} 2--------\mathrm{bxn}$,

$\mathrm{Y}=-25.383+0.856$ (Max. Temp. July-August) + 0.29(Min Temp Mid March-July)

-0.003 (Rainfall Amount February) - 0.03 (rainfall amount July-August).

This trend line shows maximum temperature as having the strongest positive influence on rice yield during harvesting, followed by minimum temperature showing positive relationship during growing season and rainfall amount showing a mild negative correlation at the period of rice harvesting.

\section{SUMMARY AND CONCLUSION}

The climate effect of upland rice was examined in Ekiti State. In order to increase yield more land is put into cultivation. This can result in a mis-match of rice crop and the environment. High rainfall is required during planting season while air temperature is very important during rice harvesting. In conclusion farmers should be enlightened on the harmful repercussion of increasing farm land area to increase rice yield. Further study of this kind should investigate the effect of climate on swamp rice which is also grown in the area.

\section{REFERENCES}

Adetayo, A.O. \& Bello, N.J. (2011). Effect of Climate Change on Growth and Yield of Some Selected Varieties of Cowpea (Vigna Unguiculata) in the Forest-Savannah Eco-Climate Zone of Nigeria. NMets 2011 Conference Proceedings, 389-399. DOI: http://dx.doi. org/10.9790/2380-0233035

Asikhia, M.O. \& Igbafen M.O. (2012). Food Security Implication of Climate Change and Loss of Biodiversity. Book of Proceeding of the 2012 Annual Conference of Nigerian Meteorological Society held at the Department Geography and Regional Planning, University of Benin City, Edo State, 83-90. DOI: http://dx.doi.org/10.15580/gjss.2012.1.gjss1204

Auffhammer, M., Ramanathan, V. \& Vincent, J.R. (2011). Climate Change, the Monsoon, and Rice Yield in India. Available online at: www.ramanathan.ucsb.edu/files/pr186pdf. DOI: http:// dx.doi.org/10.1007/s10584-011-0208-4

Ayinde, O.E., Ojehomon, V.E.T. Daramola, F.S. \& Falaki, A.A. (2013). Evaluation of the Effects of Climate Change on Rice Production in Niger State, Nigeria. Ethiopian Journal of Environmental Studies and Management 6 (Supplementary 2013). 763 - 773. DOI: http:// dx.doi.org/10.4314/ejesm.v6i6.7s

Basorun, O.J. \& Juluis O.F. (2012). Factor Influencing Rice Production in Igbemo-Ekiti Region of Nigeria. Journal of Agriculture, Food and Environmental Sciences 5(1). DOI: http://dx.doi. org/10.3844/jssp.2010.41.46 
Besir, K. \& Ceylan, M. (2013). Effect of Climate Change on Rice Production: The Case of Turkey. Journal of Agricultural Research 8(23), 2903 - 2910. DOI: http://dx.doi.org/10.3923/ ajar.2009.18.27

FAO (1996). Production Year Book Vol.50. Rome. DOI: http://dx.doi.org/10.1163/1570-6664_ iyb_sim_org_2193

Mohammad, H. Akhadelor M.O. \& Isiaka, T.S. (2011). A Comparative Assessment of the Response of Quality Protein Maize Varieties to Rainfall and Soil in the Sudan and Guinea Savannah. NMets 2011 Conference Proceedings, 444-454. DOI: http://dx.doi.org/10.1016/j. fcr.2011.01.010

NISER (2002). Assessment of the Economic, Social and Environmental Impact of Rice Production in Nigeria with the Trade Liberian Framework. A Research Paper. DOI: http://dx.doi. org/10.1016/s0195-9255(97)00083-8

Nwalieji, H.U. \& Uzuegbunam, C.O. (2012). Effect of Climate Change on Rice Production in Anambra State, Nigeria. Journal of Agricultural Extension 16(2), Available online at: www. ajol.info/index.php/jae/article/viee/81522. DOI: http://dx.doi.org/10.4314/jae.v16i2.7

Nwosu, N.I. (1998). Methods of correlation Analysis. In: A. Adedayo and N. Nwosu (eds) Elements of Social Science Statistics. Shebotimo Publications Ijebu-Ode, Nigeria. DOI: http://dx.doi. org/10.4314/jbi.v3i1.30400

Olanrewaju, R.M. (2010). Climate and Rice Production in a Part of the Niger River Basin Development Authority Area (NRBDA): A Case Study of Edu and Lafiagi Local Government Areas of Kwara State, Nigeria. Journal of Meteorology and Climate Science 8 (2), 102-110. DOI: http://dx.doi.org/10.4172/2157-7617.1000230

Sawa, B.A. \& Adebayo, A.A. (2011). Relationship between Dry Spells and Crop Yield in Drought Prone Areas of Northern Nigeria NMets 2011 Conference Proceedings,502-525. DOI: http:// dx.doi.org/10.1016/b978-0-444-88912-6.50011-6

Scharticles (2014). Effects of Climate Change on Rice Production: Project Materials, Term Papers, Thesis for Schools. Available online at: www.scharticles.com/effects-climate-changericeproduction. DOI: http://dx.doi.org/10.1007/978-3-642-40455-9_84-1

Tyubee, T.B. (2006). An Analysis of Food Crop Yield and Climate Relates in Benue State, Nigeria. Journal of Nigerian Meteorological Society 6(1), 13-22.DOI: http://dx.doi.org/10.9790/08371314549.

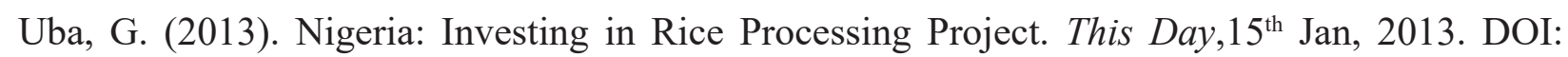
http://dx.doi.org/10.1109/epe.2013.6634733

Ugwu, C. (2013). Challenges of Rice Production in Nigeria: Punch, $4^{\text {th }} 2014$.

Ugwu, C. (2014). Local Rice; Nigeria to make \#300bn; Ekiti \#6bn. Vanguard Sunday May, $4^{\text {th }}$ 2014. Ekiti is One of the Leading 13 Rice Producing States in Nigeria. 